Research Article

\title{
Phytochemical Analysis and Evaluation of Biological Activity of Lawsonia inermis Seeds Related to Alzheimer's Disease
}

\author{
Majid Balaei-Kahnamoei ${ }^{(D)},{ }^{1}$ Mina Saeedi $\left(D,{ }^{2,3}\right.$ Arezoo Rastegari $\left(\mathbb{D},{ }^{3}\right.$ \\ Mohammad Reza Shams Ardekani $\mathbb{D}^{1,3}$ Tahmineh Akbarzadeh $\mathbb{D}^{4},{ }^{4}$ \\ and Mahnaz Khanavi $\mathbb{D D}^{1,3,5}$ \\ ${ }^{1}$ Department of Pharmacognosy, Faculty of Pharmacy, Tehran University of Medical Sciences, Tehran, Iran
${ }^{2}$ Medicinal Plants Research Center, Faculty of Pharmacy, Tehran University of Medical Sciences, Tehran, Iran
${ }^{3}$ Persian Medicine and Pharmacy Research Center, Tehran University of Medical Sciences, Tehran, Iran
${ }^{4}$ Department of Medicinal Chemistry, Faculty of Pharmacy, Tehran University of Medical Sciences, Tehran, Iran
${ }^{5}$ Faculty of Land and Food Systems, University of British Columbia, Vancouver, British Columbia, Canada
}

Correspondence should be addressed to Mahnaz Khanavi; khanavim@tums.ac.ir

Received 7 May 2021; Revised 12 June 2021; Accepted 1 July 2021; Published 19 July 2021

Academic Editor: Wen yi Kang

Copyright (C) 2021 Majid Balaei-Kahnamoei et al. This is an open access article distributed under the Creative Commons Attribution License, which permits unrestricted use, distribution, and reproduction in any medium, provided the original work is properly cited.

Using Lawsonia inermis L. (henna) seeds has been frequently recommended for the improvement of memory in Iranian Traditional Medicine (ITM). In this respect, different fractions of the plant were prepared and evaluated for their in vitro biological assays related to Alzheimer's disease (AD), including acetylcholinesterase (AChE) and butyrylcholinesterase (BChE) inhibitory activity as well as metal chelating ability and DPPH antioxidant activity. The dichloromethane and ethyl acetate fractions were able to inhibit the BChE selectively with $\mathrm{IC}_{50}$ values of 113.47 and $124.90 \mu \mathrm{g} / \mathrm{mL}$, respectively, compared with donepezil as the reference drug $\left(\mathrm{IC}_{50}=1.52 \mu \mathrm{g} / \mathrm{mL}\right)$. However, all fractions were inactive toward AChE. Phytochemical analysis of the dichloromethane fraction indicated the presence of $\beta$-sitosterol (1), 3-O- $\beta$-acetyloleanolic acid (2), 3-O-(Z)-coumaroyl oleanolic acid (3), betulinic acid (4), and oleanolic acid (5). The inhibitory activity of isolated compounds was also evaluated toward AChE and BChE. Among them, compounds 2 and 5 showed potent inhibitory activity toward BChE with IC $_{50}$ values of 77.13 and $72.20 \mu \mathrm{M}$, respectively. However, all compounds were inactive toward AChE. Moreover, molecular docking study confirmed desired interactions between those compounds and the BChE active site. The ability of fractions and compounds to chelate biometals $\left(\mathrm{Cu}^{2+}, \mathrm{Fe}^{2+}\right.$, and $\left.\mathrm{Zn}^{2+}\right)$ was also investigated. Finally, DPPH antioxidant assay revealed that the ethyl acetate $\left(\mathrm{IC}_{50}=3.08 \mu \mathrm{g} / \mathrm{mL}\right)$ and methanol $\left(\mathrm{IC}_{50}=3.64 \mu \mathrm{g} / \mathrm{mL}\right)$ fractions possessed excellent antioxidant activity in comparison to BHA as the positive control $\left(\mathrm{IC}_{50}=3.79 \mu \mathrm{g} / \mathrm{mL}\right)$.

\section{Introduction}

Alzheimer's disease (AD) is characterized as the most common neurodegenerative disease leading to a gradual decrease in memory, cognitive disorders, psychological and behavioral disturbances, and serious problems in daily activities. Also, it accounts for more than $70 \%$ of dementia cases in elderly people worldwide [1]. The number of patients with AD is predicted to be triple in 2050 [2]. Not only the increasing number of patients with $\mathrm{AD}$ in both developed and developing countries, but also the economic burden of disease has encouraged the researchers to develop efficient anti-AD drugs [3].

$\mathrm{AD}$ is the consequence of multiple etiological factors including genetics, environment, and lifestyle [4]. The exact origin of $\mathrm{AD}$ is not clear and different factors including reduced levels of acetylcholine $(\mathrm{ACh})$ in the brain [5], intracellular hyperphosphorylation of tau protein and formation of neurofibrillary tangles (NFTs) [6], accelerated aggregation of $\beta$-amyloid peptides [7], dyshomeostasis and miscompartmentalization of the biometal ions $\left(\mathrm{Fe}^{2+}, \mathrm{Cu}^{2+}\right.$, and $\left.\mathrm{Zn}^{2+}\right)$ [8], calcium overload 
and mitochondrial disruption [9], and oxidative stress due to the generation of reactive oxygen species (ROS) [10] play important roles in the onset and progression of the disease.

Now, it is clear that ACh levels in the hippocampus and cortex are crucial for the regulation of memory, attention, learning, and motivation [11]. Cholinesterases (ChEs) including acetylcholinesterase (AChE) and butyrylcholinesterase (BChE) are two cholinergic enzymes involved in the hydrolysis of ACh into choline and acetic acid to terminate synaptic transmission in the brain. In spite of the fact that physiological function of $\mathrm{AChE}$ at cholinergic synapses is well articulated, the function of $\mathrm{BChE}$ has still not been clarified [12]. In a healthy brain, both activity and concentration of $\mathrm{AChE}$ are more dominant than those of BChE. BChE has shown low activity in hydrolytic reactions and mainly distributed in plasma and tissues. However, the supportive role of this enzyme in synaptic transmission has been proven $[13,14]$. During the progression of $\mathrm{AD}$, hydrolysis of ACh is performed by BChE as the level of AChE shows a steady decline to $50 \%$, that of $\mathrm{BChE}$ reaches $900 \%$, and the $\mathrm{BChE} / \mathrm{AChE}$ ratio also increases significantly [15]. It has been demonstrated that $\mathrm{BChE}$ regulates ghrelin levels in male $\mathrm{BALB} / \mathrm{c}$ mice, which is responsible for emotional and social behaviors such as aggression [16]. Moreover, BChE activity was found to be very high in the hippocampus of patients with $\mathrm{AD}$, the tissue which is strongly associated with cognitive functions [17]. All these indicate that the inhibition of AChE alone does not afford a proper planning process for the treatment of $\mathrm{AD}$ and the inhibition of $\mathrm{BChE}$ should also be considered.

Currently, there is no definite cure for $\mathrm{AD}$, and most available drugs approved by FDA, such as donepezil, galantamine, and rivastigmine, are $\mathrm{ChE}$ inhibitors that improve cognitive disorders and the disease symptoms [18]. In this respect, development of $\mathrm{ChE}$ inhibitors is still in demand and it should be noted that selective anti-AChE activity can be achieved by small molecules, while selective anti-BChE activity is possible by bulky ligands since BChE has displayed low substrate specificity [19]. Another point that highlights the importance of the inhibition of ChEs is their noncholinergic role especially that of $\mathrm{BChE}$ in the deposition of $\beta \mathrm{A}$ plaques [20].

The development of anti-AD drugs is directly affected by the multifactorial nature of the disease; hence, medicinal plants possessing a wide range of phytochemicals are the potent candidates for the AD drug discovery [21]. Lawsonia inermis L., commonly known as "henna" [22], belongs to Lythraceae family and is a native of Southwest Asia and North Africa [23]. L. inermis is known for its valuable applications in the cosmetic industry [24] and traditional therapeutic properties such as edema, bronchitis, rheumatism, smallpox, spermatorrhoea, menstrual disorders, and hemorrhoids [25]. Antidiarrheal, anti-inflammatory, analgesic, antipyretic, antibacterial especially Gram-positive bacteria, and antifungal properties against Trichophyton, Sporotrichum, and Cryptococcus have been recorded in the literature [26]. According to Iranian Traditional Medicine (ITM), consuming henna seeds with honey and tragacanth strengthens and improves memory [27]. Herein, in continuation of our efforts on development of herbal anti-AD agents [28-32], we selected $L$. inermis seeds to evaluate different biological activities related to $\mathrm{AD}$ including in vitro ChEs inhibitory activity as well as metal chelating ability (copper, iron, and zinc ions) and DPPH antioxidant activity. Also, according to the efficacy of dichloromethane fraction, phytochemical analysis led to the isolation and identification of five compounds that have not been previously reported for henna seeds.

\section{Materials and Methods}

2.1. General Experimental Procedures. Melting points were determined on a Kofler hot stage apparatus and are uncorrected. NMR spectra were recorded on an Avance III spectrometer (Bruker) operating at $400.20 \mathrm{MHz}$ for ${ }^{1} \mathrm{H}$ NMR and $100.63 \mathrm{MHz}$ for ${ }^{13} \mathrm{C}-\mathrm{NMR}$ as well as $2 \mathrm{D} \mathrm{HMBC}$, COSY, and HSQC experiments. Silica gel for column chromatography (70-230 and 230-400 mesh) and precoated silica gel $\mathrm{F}_{254}(20 \times 20 \mathrm{~cm})$ plates for TLC were purchased from Merck. TLC plates were visualized under UV light (254 and $366 \mathrm{~nm}$ ) as well as spraying anisaldehyde-sulfuric acid, followed by heating at $150^{\circ} \mathrm{C}$.

2.2. Chemical and Reagents. Acetylcholinesterase (AChE, E.C. 3.1.1.7, Type V-S, lyophilized powder, from electric eel, 1000 units), butyrylcholinesterase (BChE, E.C. 3.1.1.8, from equine serum), acetylthiocholine iodide (ATCI), and 5,5dithiobis-2-nitrobenzoic acid (DTNB) were purchased from Sigma-Aldrich. Potassium dihydrogen phosphate, dipotassium hydrogen phosphate, potassium hydroxide, and sodium hydrogen carbonate were obtained from Fluka. Solvents for the extraction and column chromatography (CC) were of technical grade and redistilled before use. Deuterated solvents (100 atom \% D) were obtained from Sigma-Aldrich.

2.3. Plant Material. Fresh and healthy fruits of Lawsonia inermis L. were collected from the southern coast of Iran, Hormozgan Province, Bandar Abbas City, and the taxonomic identities of the plant were authenticated by Doctor Ajani, a taxonomist at the Research Institute of Forests and Rangelands, and deposited in the Herbarium of Faculty of Pharmacy, Tehran University of Medical Sciences (voucher specimen no. 7028-TEH).

2.4. In Vitro AChE/BChE Inhibition Assay. In vitro anti-ChEI activity was performed against acetylcholinesterase (AChE, E.C. 3.1.1.7, Type V-S, lyophilized powder, from electric eel, 1000 units) and butyrylcholinesterase (BChE, E.C. 3.1.1.8, from equine serum) using the modified Ellman's method [33]. To obtain acceptable enzyme inhibitory activity $(20-80 \%)$, the stock solutions of the fractions $(10 \mathrm{mg} / \mathrm{mL})$ and compounds $(1 \mathrm{mg} / \mathrm{mL})$ were prepared in DMSO and were diluted with a mixture of DMSO and methanol to achieve four different final concentrations of the fractions 
$(63.5,125,250,500 \mu \mathrm{g} / \mathrm{mL})$ and compounds $(1,10,20,40 \mu \mathrm{g} /$ $\mathrm{mL}$ ), while obtaining the final ratio of 50/50 DMSO/ methanol. Each well consisted of $50 \mu \mathrm{L}$ potassium phosphate buffer $\left(\mathrm{KH}_{2} \mathrm{PO}_{4} / \mathrm{K}_{2} \mathrm{HPO}_{4}, 0.1 \mathrm{M}, \mathrm{pH} 8\right), 25 \mu \mathrm{L}$ prepared sample as described above, and AChE enzyme $(25 \mu \mathrm{L})$ with a final concentration of 0.22 units $/ \mathrm{mL}$ in the buffer. They were preincubated for $15 \mathrm{~min}$ at room temperature, and then, $125 \mu \mathrm{L}$ DTNB ( $3 \mathrm{mM}$ in buffer) was added to the mixture. Following the addition of $25 \mu \mathrm{L}$ substrate ATCI $(3 \mathrm{mM}$ in water), changes in the absorbance were spectrometrically measured at $405 \mathrm{~nm}$ using a UV Unico Double Beam spectrophotometer. In parallel, a blank containing all components without enzyme was used in order to account for the nonenzymatic reaction. A negative control was also used under the same conditions without inhibitor, and donepezil was used as the positive control. The $\mathrm{IC}_{50}$ values were determined graphically from log concentration vs. $\%$ of inhibition curves. All experiments were performed in triplicate. BChE inhibition assay was performed in the same method.

2.5. Metal Ion Chelating Ability. All solutions used in metal chelating study were prepared in methanol. The solutions of $\mathrm{Fe}^{2+}, \mathrm{Cu}^{2+}$, and $\mathrm{Zn}^{2+}$ ions were obtained from $\mathrm{FeSO}_{4} \cdot 7 \mathrm{H}_{2} \mathrm{O}$, $\mathrm{CuCl}_{2} \cdot 2 \mathrm{H}_{2} \mathrm{O}$, and $\mathrm{ZnCl}_{2}$, respectively. To investigate the biometal chelating ability, a solution of compound or fraction at distinct concentration $(1 \mathrm{~mL})$ was mixed with the metal solution $(1 \mathrm{~mL})$ at the same concentration in a $1 \mathrm{~cm}$ quartz cuvette, and the mixture was left at room temperature for $30 \mathrm{~min}$. Then, the absorbance of the solution was read in the wavelength range of $260-500 \mathrm{~nm}$ [34].

2.6. Antioxidant Activity by DPPH Test. Several concentrations of the test fraction in $\mathrm{MeOH}$ were prepared. Aliquots of different concentrations of the fraction $(1 \mathrm{~mL})$ were added to the DPPH methanolic solution $(1.0 \mathrm{~mL}, 0.1 \mathrm{mM})$, and the mixtures were shaken vigorously and left for $30 \mathrm{~min}$ at room temperature in the dark. The absorbance was then measured at $517 \mathrm{~nm}$ using a UV/visible spectrophotometer. The percent scavenging activity was calculated using the following formula:

$$
\text { inhibition }(\%)=\left[1-\frac{A \text { (sample })-A \text { (blank) }}{A \text { (control) }}\right] \times 100 \text {, }
$$

where A (sample) is the absorbance of the fractions, A (blank) is the maximum concentration of samples without $\mathrm{DPPH}$, and A (control) is the absorbance of the DPPH.

In the same procedure, butylated hydroxyanisole (BHA) was used as the positive control. The DPPH radical scavenging activity of the fractions was expressed as $\mathrm{IC}_{50}(\mu \mathrm{g} /$ $\mathrm{mL}$ ), which is obtained from linear regression plot between concentrations of the test fractions and percent inhibitions.

2.7. Molecular Docking Study. A molecular docking study was carried out using the Autodock 4.2.6 program for compounds 2 and 5 . The crystal structure of apo BChE (PDB
ID: 4TPK) was retrieved from the Protein Data Bank (http://www.rcsb.org). The 3D structure of donepezil (positive control) was obtained from the DrugBank database (https://go.drugbank.com). The 2D structures of the desired compounds were drawn on ChemDraw Professional 16.0, and 3D structures were generated using Chem3D suite, saved in .pdb format, and converted to .pdbqt format coordinate by AutoDockTools (ADT). Moreover, for preparation of the pdbqt form of the enzymes, polar hydrogen atoms were added to amino acid residues and Kollman charges were assigned to all atoms using ADT, and the obtained enzyme .pdbqt was used as an input for the Autogrid program. In Autogrid for each atom type, the inhibitor's maps were calculated with $0.375 \mathrm{~A}^{\circ}$ spacing between grid points, and the center of the grid box was placed $x=1.176, y=11.017$, and $z=11.175$ for BChE. The dimensions of the active site box were set at $40 \times 40 \times 40 \times \mathrm{A}^{\circ}$ for $\mathrm{BChE}$ [35]. Flexible ligand dockings were accomplished for the selected compounds. The docking was carried out with 100 runs using the Lamarckian genetic algorithm (LGA). Other parameters were accepted as default. The calculated geometries were ranked in terms of free energy of binding and the best pose was selected for further analysis. Molecular visualizations were performed by Discovery Studio 4.0 client software.

2.8. Extraction and Isolation. After drying the fruits of the plant in the shade and away from the sun, the seeds, a brown cone, were carefully separated from the capsule-like fruits, and then, the skin of the fruits and other plant organs were removed. Next, $400 \mathrm{~g}$ seeds were milled using a laboratoryscale mill and extracted with methanol $(\mathrm{MeOH}) 100 \%$ $(5 \times 2 \mathrm{~L})$ for $72 \mathrm{~h}$ at room temperature. The collected extract was concentrated under vacuum at $40^{\circ} \mathrm{C}$ using a rotary evaporator, and finally, $84.20 \mathrm{~g}$ dry extract was obtained, yielding $21.05 \%$. This extract was subjected to silica gelcolumn chromatography (CC) (400 g, 70-230 mesh, $10 \times 30 \mathrm{~cm})$ and washed with petroleum ether $(\mathrm{PE})$, dichloromethane (DCM), ethyl acetate (EtOAc), and $\mathrm{MeOH}$ (4 L per solvent), respectively.

The DCM fraction was loaded onto a silica gel vacuum liquid chromatography (VLC) (200 g, 70-230 mesh, $4.5 \times 70 \mathrm{~cm}$ ), eluted with a gradient of the PE:DCM, and then DCM: acetone (ACE). Totally, 13 fractions (F1-F13) were combined with the aid of TLC analysis (bands were detected on TLC under UV (254 nm and $360 \mathrm{~nm})$ and spraying anisaldehyde-sulfuric acid, followed by heating at $150^{\circ} \mathrm{C}$.

Fraction F4 (250 mg, eluted with DCM 100\%) was applied on silica gel CC $(60 \mathrm{~g}, 70-230 \mathrm{mesh}, 2 \times 70 \mathrm{~cm})$ and eluted with a gradient of the PE:ACE $(95: 5$ to $80: 20)$ to afford six subfractions (SFs. 4a-4f). Subfraction $4 \mathrm{~d}$ was recrystallized from chloroform to give compound $\mathbf{1}(4 \mathrm{mg})$. Fraction F5 (500 mg, eluted with DCM: ACE (99:1)) was subjected to another silica gel CC $(60 \mathrm{~g}, 70-230$ mesh, $2 \times 70 \mathrm{~cm}$ ), eluted with a gradient of the PE : ACE $(90: 10$ to $65: 35$ ) to afford three subfractions (SFs. 5a-5c). Subfraction $5 \mathrm{~b}$ was further separated on silica gel CC $(45 \mathrm{mg}, 230-400$ mesh, $2 \times 70 \mathrm{~cm})$, eluted with PE:ACE $(85: 15)$ to give 
compound 2 (10 mg). Fraction F8 (600 mg, eluted with DCM : ACE (96:4)) was separated over a silica gel CC (40 g, 230-400 mesh, $1.5 \times 70 \mathrm{~cm}$ ) with a gradient mixture of PE: ACE $(80: 20$ to $0: 100)$ as eluent, to afford thirteen subfractions (SFs. 8a-8m). Subfraction $8 \mathrm{f}$ was triturated with EtOAc to give an insoluble solid, which was recrystallized from $\mathrm{MeOH}$ to afford compound $3(8 \mathrm{mg})$. Subfraction $8 \mathrm{~d}$ was loaded onto silica gel CC $(65 \mathrm{mg}$, 230-400 mesh, $2 \times 100 \mathrm{~cm})$, eluted with a gradient mixture of $n$-hexane : ethyl acetate $(80: 20)$ to give five subfractions (SFs. 8d1-8d5). Two subfractions, 8d1 and $8 \mathrm{~d} 3$, were recrystallized from $\mathrm{MeOH}$ to afford compound $4(7 \mathrm{mg})$ and compound $5(8 \mathrm{mg})$, respectively.

\section{Results and Discussion}

3.1. Isolated Compounds from Henna Seeds. Phytochemical analysis of dichloromethane fraction of L. inermis seeds was conducted using silica gel column chromatography to isolate and characterize five compounds 1-5 for the first time for henna seeds (Figure 1). All data from the characterization of compounds 1-5 were compared with those reported in the literature [36-40].

$\beta$-Sitosterol (1): colorless needles ( $4 \mathrm{mg}), \mathrm{mp}: 134-137^{\circ} \mathrm{C}$. ${ }^{1} \mathrm{H} \mathrm{NMR}\left(400 \mathrm{MHz}, \mathrm{CDCl}_{3}\right) \delta=5.35(1 \mathrm{H}, d, J=5.3 \mathrm{~Hz}, \mathrm{H}-6)$, $3.52(1 \mathrm{H}, m, \mathrm{H}-3), 1.01(3 \mathrm{H}, \mathrm{s}, \mathrm{Me}-19), 0.92(3 \mathrm{H}, d, J=6.6 \mathrm{~Hz}$, Me-21), 0.79-0.87 (9H, $m, \mathrm{Me}-29, \mathrm{Me}-26, \mathrm{Me}-27), 0.68$ (3H, s, Me-18). ${ }^{13} \mathrm{C} \mathrm{NMR}\left(125 \mathrm{MHz}, \mathrm{CDCl}_{3}\right.$, based on DEPT, HMQC and HMBC experiments; see Table 1) [36].

3-O- $\beta$-Acetyloleanolic acid (2): colorless crystal; m.p. $>250^{\circ} \mathrm{C}$. ${ }^{1} \mathrm{H} \mathrm{NMR}\left(400 \mathrm{MHz}, \mathrm{CDCl}_{3}\right) \delta=5.27(1 \mathrm{H}, m, \mathrm{H}-12)$, 4.49 (1H, $m, \mathrm{H}-3), 2.82$ (1H, dd, $J=13.9,4.6 \mathrm{~Hz}, \mathrm{H}-18), 2.05$ (3H, s, 3-OAc), 0.74, 0.85, 0.86, 0.90, 0.93, 0.94, $1.12(21 \mathrm{H}, s$, $\left.\mathrm{CH}_{3} \times 7\right) .{ }^{13} \mathrm{C} \mathrm{NMR}\left(125 \mathrm{MHz}, \mathrm{CDCl}_{3}\right.$, based on DEPT, HMQC and HMBC experiments; see Table 1) [37].

3-O-(Z)-Coumaroyl oleanolic acid (3): white powder, m.p. $>250^{\circ} \mathrm{C} .{ }^{1} \mathrm{H} \mathrm{NMR}\left(400 \mathrm{MHz}\right.$, DMSO- $\left.d_{6}\right): \delta=7.61$ $\left(2 \mathrm{H}, d, J=8.5 \mathrm{~Hz}, \mathrm{H}-5^{\prime}\right.$ and $\left.\mathrm{H}-9^{\prime}\right), 7.60(1 \mathrm{H}, d, J=16.1 \mathrm{~Hz}$, $\left.\mathrm{H}-3^{\prime}\right), 6.86\left(2 \mathrm{H}, d, J=8.5 \mathrm{~Hz}, \mathrm{H}-6^{\prime}\right.$ and $\left.\mathrm{H}-8^{\prime}\right), 6.43(1 \mathrm{H}, d$, $\left.J=16.1 \mathrm{~Hz}, \mathrm{H}-2^{\prime}\right), 5.24$ (1H, bs, H-12), 4.59 (1H, dd, $J=11.4,4.3 \mathrm{~Hz}, \mathrm{H}-3), 1.19,0.99,0.97,0.95,0.95,0.92,0.81$ $\left(21 \mathrm{H}, s, \mathrm{CH}_{3} \times 7\right) .{ }^{13} \mathrm{C} \mathrm{NMR}\left(125 \mathrm{MHz}, \mathrm{CDCl}_{3}\right.$, based on DEPT, HMQC, and HMBC experiments); see Table 1 [38].

Betulinic acid (4): white amorphous powder, m.p. $>250^{\circ} \mathrm{C} .{ }^{1} \mathrm{H}$ NMR $\left(400 \mathrm{MHz}, \mathrm{DMSO}-\mathrm{d}_{6}\right) \delta=12.07(1 \mathrm{H}, s$, $-\mathrm{COOH}), 4.69(1 \mathrm{H}, d, J=1.8 \mathrm{~Hz}, \mathrm{H} 29 \mathrm{a}), 4.78(1 \mathrm{H}, t$, $J=1.8 \mathrm{~Hz}, \mathrm{H}-29 \mathrm{~b}), 4.28\left(1 \mathrm{H}, d, J=5.1, \mathrm{OH}-\mathrm{C}_{3}\right), 2.96(2 \mathrm{H}, m$, $\mathrm{H}-3$ and H-19), 1.65, 0.94, 0.88, 0.88, 0.77, $0.65(21 \mathrm{H}, s$, $\left.\mathrm{CH}_{3} \times 7\right) .{ }^{13} \mathrm{C} \mathrm{NMR}\left(125 \mathrm{MHz}, \mathrm{CDCl}_{3}\right.$, based on DEPT, HMQC, and HMBC experiments; see Table 1) [39].

Oleanolic acid (5): white amorphous powder, m.p. $>250^{\circ} \mathrm{C}$. ${ }^{1} \mathrm{H} \mathrm{NMR}\left(400 \mathrm{MHz}, \mathrm{CDCl}_{3}\right) \delta=12.05(1 \mathrm{H}, \mathrm{bs}$, HOO-C 28 ), 5.19 (1H, $m, \mathrm{H}-12), 4.32(1 \mathrm{H}, d, J=5.1 \mathrm{~Hz}, \mathrm{OH}-$ $\left.\mathrm{C}_{3}\right), 3.03(1 \mathrm{H}, m, \mathrm{H}-3), 2.77(1 \mathrm{H}, \mathrm{dd}, J=13.9,4.6 \mathrm{~Hz}, \mathrm{H}-18)$, $1.84(1 \mathrm{H}, \mathrm{dd}, J=9.0,3.6 \mathrm{~Hz}, \mathrm{H}-9), 1.26,1.12,0.92,0.90,0.88$, $0.74,0.70\left(21 \mathrm{H}, s, \mathrm{CH}_{3} \times 7\right), 0.69(1 \mathrm{H}, \mathrm{bs}, \mathrm{H}-5) .{ }^{13} \mathrm{C} \mathrm{NMR}$ $\left(125 \mathrm{MHz}, \mathrm{CDCl}_{3}\right.$, based on DEPT, HMQC, and HMBC experiments; see Table 1) [40].
3.2. Anticholinesterase Inhibitory Activity . As anticholinesterases are still prescribed for the treatment of symptoms and cognitive impairment in patients with $\mathrm{AD}$ [41], potency of $L$. inermis seeds absorbed our attention due to recommendations in ITM. In this respect, all fractions and isolated compounds were screened for their in vitro $\mathrm{AChE}$ and $\mathrm{BChE}$ inhibitory activity using a 96-well microplate reader according to the modified Ellman's method [42] comparing with donepezil as the reference drug $\left(\mathrm{IC}_{50}=1.52 \mu \mathrm{g} / \mathrm{mL}\right)$ (Table 2).

It should be noted that all fractions and compounds 1-5 demonstrated no AChEI activity; however, results related to the selective anti-BChE activity were worth considering. As can be seen in Table 2, DCM and EtOAc fractions were the most potent and selective inhibitors of $\mathrm{BChE}$ with $\mathrm{IC}_{50}$ values of $113.47 \pm 1.25$ and $124.90 \pm 1.15 \mu \mathrm{g} / \mathrm{mL}$, respectively, whereas the other fractions were not active. In the case of isolated compounds, compounds $\mathbf{2}$ and $\mathbf{5}$ depicted selective BChE inhibitory activity with $\mathrm{IC}_{50}$ values of $77.13 \pm 0.01$ and $72.20 \pm 0.42 \mu \mathrm{M}$, respectively.

The compensatory role of BChE in late-stage or advanced $\mathrm{AD}$ has been fully proven and the enzyme is responsible for the reduction of the ACh levels in the brain. Also, BChE plays an important role in the transformation of nonfibrillary to fibrillar $\mathrm{A} \beta$ plaques and senile plaques. It seems that inhibition of $\mathrm{BChE}$ can be considered as a therapeutic target in the treatment of $\mathrm{AD}$ [43]. In this respect, medicinal plants and natural products have been found to possess desired anticholinesterase activity. Plantderived alkaloids, such as physostigmine, galantamine, sanguinine, and huperzine $\mathrm{A}$, have shown significant inhibitory activity against acetylcholinesterase [44]. Terpenes, sterols, flavonoids, and glycosides have also been reported to possess anti-ChE activity [45]. Among fifteen compounds isolated from Gelsemium elegans and Aglaia odorata, paeonol and hydroperoxy-24-vinylcholesterol exhibited selective BChE inhibitory activity [46]. Also, sixteen lanostane triterpenes obtained from fruiting bodies of Ganoderma lucidum were selective inhibitors of AChE [44]. All these findings revealed that medicinal plants are the most credible source of ChE inhibitors.

The effect of $L$. inermis has been investigated from different points of view. Amat-ur-Rasool et al. reported that the methanolic extract of henna leaves had strong in vitro AChEI and BChEI activity with $\mathrm{IC}_{50}$ values of 0.33 and $0.41 \mathrm{mg} / \mathrm{mL}$, respectively [47]. Also, study of the ethanolic extract of henna leaves against scopolamineinduced memory impairment in Swiss albino mice revealed that using the extract at the doses of $200 \mathrm{mg} / \mathrm{kg}$ and $400 \mathrm{mg} / \mathrm{kg}$ for 7 days inhibited AChE significantly as compared with the control group [48]. As reported by Mir et al., in vivo investigation of the ethyl acetate and chloroform extracts of $L$. inermis leaves at a dose of $25 \mathrm{mg} /$ $\mathrm{kg}$ indicated their memory-enhancing potentials using two methods including "without inducing amnesia" and "induction of amnesia" by administration of diazepam as well as the cognitive improvements using behavioral models including elevated plus maze (EPM) and the passive shock avoidance (PSA) paradigm [49]. 


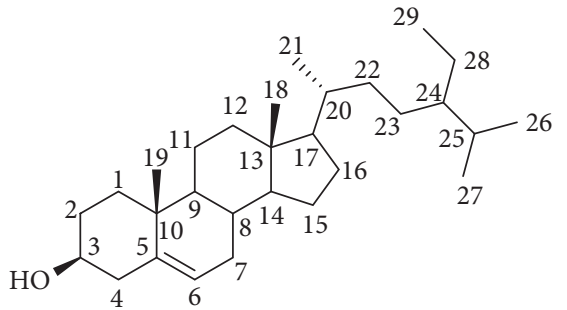

$\beta$-Sitosterol (1)

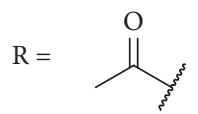

3-O- $\beta$-Acetyloleanolic acid (2)

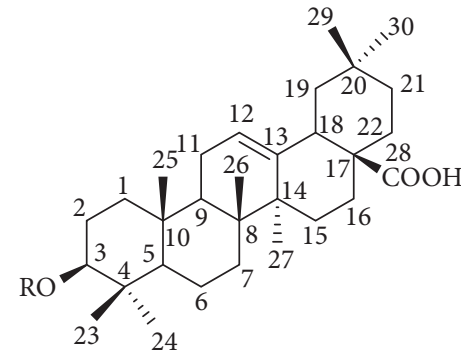

24<smiles></smiles>

3-O-(Z)-Coumaroyl oleanolic acid (3)

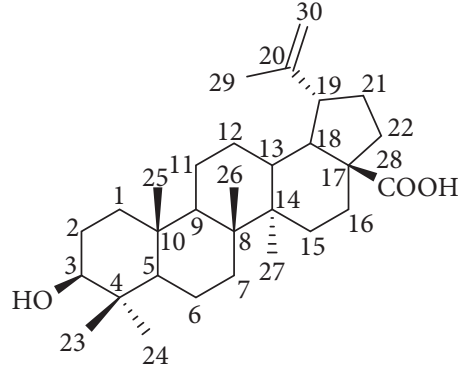

Betulinic acid (4)

$\mathrm{R}=\mathrm{H}$

Oleanolic acid (5)

FIgURE 1: The structure of isolated compounds (1-5) from $L$. inermis seeds.

3.3. Metal Ion Chelating Activity. Redox-active metals such as $\mathrm{Fe}^{2+}, \mathrm{Zn}^{2+}$, and $\mathrm{Cu}^{2+}$ can increase the toxicity of $\mathrm{A} \beta$ plaques by forming coordinate bonds. Also, excessive accumulation of metal ions and interaction with $\beta$-amyloid plaques leads to oxidative stress due to an increased formation of reactive oxygen species (ROS). It seems that the biometal chelation hypothesis can be considered as a strong therapeutic tool in the treatment of $\mathrm{AD}$ [28]. Thus, the metal chelating ability of all fractions and isolated compounds 1-5 was investigated. For this purpose, the UV-visible absorption spectra were recorded in the wavelength range of 260-500 nm and compared with those obtained from the treated solution of fractions or compounds with $\mathrm{Fe}^{2+}, \mathrm{Zn}^{2+}$, and $\mathrm{Cu}^{2+}$ ions with final concentrations of $20 \mu \mathrm{g} / \mathrm{mL}$ and $20 \mu \mathrm{M}$, respectively. Those findings indicated the desired capability of phytochemicals present in the fractions to form complexes with biometals.

The $\mathrm{MeOH}$ fraction was able to chelate $\mathrm{Cu}^{2+}$ ions more strongly than $\mathrm{Fe}^{2+}$ and $\mathrm{Zn}^{2+}$ ions. The absorbance peak of $\mathrm{MeOH}$ fraction (final concentration of $31.25 \mu \mathrm{g} / \mathrm{mL}$ ) at $286.4 \mathrm{~nm}$ changed to $284.3 \mathrm{~nm}$ after $30 \mathrm{~min}$ interaction with $\mathrm{Cu}^{2+}$ ions (Figure 2).

The EtOAc fraction (final concentration of $31.25 \mu \mathrm{g} / \mathrm{mL}$ ) showed three absorption peaks at 294.9, 290.7, and $282.1 \mathrm{~nm}$. It was capable of $\mathrm{Cu}^{2+}$ chelating as a peak at $288.5 \mathrm{~nm}$ appeared after interaction with $\mathrm{Cu}^{2+}$ ions. The interaction with $\mathrm{Fe}^{2+}$ ions led to a change in the absorption wavelength $(288.5$ and $297.1 \mathrm{~nm})$. However, the fraction could not chelate $\mathrm{Zn}^{2+}$ ions (Figure 3).

The UV spectrum of DCM fraction (final concentration of $250 \mu \mathrm{g} / \mathrm{mL}$ ) showed several absorption peaks at 326.9, $320.5,316.3,303.5,292.8$, and $286.4 \mathrm{~nm}$. Interaction of the fraction with $\mathrm{Cu}^{2+}$ ions led to the appearance of new peaks at $307.7 \mathrm{~nm}$, a red shift from 326.9 to $331.2 \mathrm{~nm}$, and a blue shift from $316.3 \mathrm{~nm}$ to $314.1 \mathrm{~nm}$. In the case of interaction with $\mathrm{Zn}^{2+}$ ions, a blue shift from 303.5 to 297.1 was clear. Interaction of the sample with $\mathrm{Fe}^{2+}$ ions demonstrated absorption peaks at 318.4, 314.1, 309.9, 301.3, 294.9, 290.7, and $286.4 \mathrm{~nm}$ (Figure 4 ).
The PE fraction (final concentration of $125 \mu \mathrm{g} / \mathrm{mL}$ ) showed an absorbance peak at $275.7 \mathrm{~nm}$. After the interaction of the fraction with $\mathrm{Cu}^{2+}$ ions, a red shift from $275.7 \mathrm{~nm}$ to $288.5 \mathrm{~nm}$ was confirmed. When it was treated with $\mathrm{Zn}^{2+}$ and $\mathrm{Fe}^{2+}$ ions, a red shift from $275.7 \mathrm{~nm}$ to $282.1 \mathrm{~nm}$ was also observed (Figure 5).

Investigation of metal chelating ability of isolated compounds 1-5 showed that only compound 3 (final concentration of $40 \mu \mathrm{M}$ ) was able to form chelates with biometals (Figure 6). Interaction of compound 3 and $\mathrm{Zn}^{2+}$ and $\mathrm{Cu}^{2+}$ ions afforded two blue shifts from 320.5 and $312.0 \mathrm{~nm}$ to 314.1 and $307.7 \mathrm{~nm}$, respectively. Moreover, the interaction of compound 3 and $\mathrm{Fe}^{2+}$ ions led to a change in the absorbance from 320.5 to $318.4 \mathrm{~nm}$ (Figure 6).

3.4. Antioxidant Activity by DPPH Assay. DPPH is a stable free radical that can accept an electron or hydrogen radical to become a stable molecule. All fractions (PE, DCM, EtOAc, and $\mathrm{MeOH}$ ) of $L$. inermis were screened for its possible antioxidant activity by 2,2-diphenyl-1-picrylhydrazyl radical (DPPH) scavenging activity comparing with butylated hydroxyanisole (BHA) as the standard drug $\left(\mathrm{IC}_{50}=3.79 \pm 0.37 \mu \mathrm{g} / \mathrm{mL}\right)$. As shown in Table 3, EtOAc and $\mathrm{MeOH}$ fractions were found to be the most potent antioxidant fractions $\left(\mathrm{IC}_{50}=3.08 \pm 0.10 \mu \mathrm{g} / \mathrm{mL}\right.$ and $3.79 \pm 0.37 \mu \mathrm{g} / \mathrm{mL}$, respectively) as potent as the positive control. However, both PE and DCM fractions showed lower antioxidant activity than BHA.

3.5. Molecular Docking Study. To gain an insight into the binding interaction of the isolated compounds ( 2 and 5 ) with BChE (PDB ID: 4TPK), molecular docking experiments were performed using the Glide module (autodock suite). Docking scores in $\mathrm{kJ} / \mathrm{mol}$ are shown in Table 4.

As shown in Figure 7, compound 2 made desired interactions with the $\mathrm{BChE}$ active site. The carbonyl group of carboxylic acid established H-bonding interaction with Glu197, Ser198, and His438 residues. Carbonyl group of 
TABLE 1: ${ }^{13} \mathrm{C}$ NMR data of isolated compounds 1-5 based on DEPT, HMQC, and HMBC experiments.

\begin{tabular}{|c|c|c|c|c|c|}
\hline \multirow{2}{*}{ Position } & \multicolumn{5}{|c|}{$\delta_{\mathrm{C}}(\mathrm{ppm})$} \\
\hline & 1 & 2 & 3 & 4 & 5 \\
\hline 1 & 37.3 & 38.1 & 37.4 & 38.4 & 38.0 \\
\hline 2 & 31.7 & 23.5 & 23.3 & 27.1 & 27.1 \\
\hline 3 & 71.8 & 80.9 & 79.7 & 76.7 & 76.8 \\
\hline 4 & 42.3 & 37.7 & 37.5 & 38.2 & 38.3 \\
\hline 5 & 140.8 & 55.3 & 54.5 & 54.8 & 54.7 \\
\hline 6 & 121.7 & 18.2 & 17.8 & 17.9 & 18.0 \\
\hline 7 & 31.9 & 32.5 & 32.0 & 33.8 & 32.0 \\
\hline 8 & 31.9 & 39.3 & 38.8 & 40.2 & 38.8 \\
\hline 9 & 50.1 & 47.5 & 46.8 & 49.8 & 47.0 \\
\hline 10 & 36.5 & 37.0 & 36.5 & 36.3 & 36.5 \\
\hline 11 & 21.1 & 22.9 & 22.8 & 20.4 & 22.8 \\
\hline 12 & 39.8 & 122.6 & 121.4 & 25.0 & 121.5 \\
\hline 13 & 42.2 & 143.6 & 144.5 & 37.5 & 143.8 \\
\hline 14 & 56.8 & 41.5 & 41.3 & 41.9 & 40.7 \\
\hline 15 & 26.1 & 27.6 & 27.2 & 30.0 & 26.9 \\
\hline 16 & 28.3 & 23.4 & 22.6 & 31.6 & 22.0 \\
\hline 17 & 56.1 & 46.5 & 45.6 & 55.4 & 45.6 \\
\hline 18 & 11.9 & 40.9 & 40.8 & 46.6 & 41.2 \\
\hline 19 & 19.4 & 45.8 & 45.4 & 48.4 & 45.4 \\
\hline 20 & 36.2 & 30.7 & 30.4 & 150.3 & 29.0 \\
\hline 21 & 18.8 & 33.8 & 33.3 & 29.1 & 33.2 \\
\hline 22 & 33.9 & 32.4 & 32.2 & 36.7 & 32.8 \\
\hline 23 & 26.1 & 28.0 & 27.8 & 28.0 & 28.2 \\
\hline 24 & 45.1 & 15.4 & 15.0 & 15.7 & 16.0 \\
\hline 25 & 29.2 & 16.7 & 16.7 & 15.9 & 15.0 \\
\hline 26 & 19.1 & 17.2 & 16.8 & 15.8 & 16.8 \\
\hline 27 & 19.8 & 25.9 & 25.5 & 14.3 & 25.5 \\
\hline 28 & 23.1 & 183.8 & 178.6 & 177.3 & 178.6 \\
\hline 29 & 12.0 & 33.1 & 32.8 & 18.9 & 30.3 \\
\hline 30 & - & 23.6 & 23.3 & 109.7 & 23.3 \\
\hline $\mathrm{CH}_{3} \mathrm{COO}$ & - & 21.3 & - & - & - \\
\hline$\overline{\mathrm{CH}_{3}} \mathrm{COO}$ & - & 171.1 & - & - & - \\
\hline $1^{\prime}$ & - & - & 166.4 & - & - \\
\hline $2^{\prime}$ & - & - & 114.5 & - & - \\
\hline $3^{\prime}$ & - & - & 143.8 & - & - \\
\hline $4^{\prime}$ & - & - & 125.0 & - & - \\
\hline $5^{\prime}$ & - & - & 130.3 & - & - \\
\hline $6^{\prime}$ & - & - & 115.7 & - & - \\
\hline $7^{\prime}$ & - & - & 159.8 & - & - \\
\hline $8^{\prime}$ & - & - & 115.7 & - & - \\
\hline $9^{\prime}$ & - & - & 130.3 & - & - \\
\hline
\end{tabular}

TABLE 2: AChE and BChE inhibitory activity of fractions and isolated compounds from L. inermis.

\begin{tabular}{lccccc}
\hline Fractions & $\mathrm{AChE} \mathrm{IC}_{50}(\mu \mathrm{g} / \mathrm{mL})$ & $\mathrm{BChE} \mathrm{IC}_{50}(\mu \mathrm{g} / \mathrm{mL})$ & Compounds & $\mathrm{AChE} \mathrm{IC}_{50}(\mu \mathrm{M})$ & $\mathrm{BChE} \mathrm{IC}_{50}(\mu \mathrm{M})$ \\
\hline $\mathrm{PE}$ & $>500$ & $>500$ & $\mathbf{1}$ & $>100$ & $>100$ \\
DCM & $>500$ & $113.47 \pm 1.25$ & $\mathbf{2}$ & $>100$ & $77.13 \pm 0.01$ \\
EtOAc & $>500$ & $124.90 \pm 1.15$ & $\mathbf{3}$ & $>100$ & $>100$ \\
MeOH & $>500$ & $>500$ & $\mathbf{4}$ & $>100$ & 7100 \\
Donepezil & $0.03 \pm 0.00$ & $1.52 \pm 0.10$ & $\mathbf{5}$ & $0.08 \pm 0.01$ & $3.99 \pm 0.27$ \\
& & & Donepezil & 0.42 \\
\hline
\end{tabular}

${ }^{*}$ Data are expressed as mean \pm SD (three independent experiments).

ester moiety formed a hydrogen bond with Ser287. Other interactions including alkyl and pi-alkyl interactions were constructed through the hydrophobic backbone of compound 2 and His438, Tr982, Ala328, and Tyr440 residues.
In the case compound 5 (Figure 8), two hydroxyl groups formed two H-bonding interactions with Gly116 and Tyr440 residues of the BChE. Alkyl and pi-alkyl interactions were constructed between hydrocarbon moiety of compound $\mathbf{5}$ and Phe329, Ala328, His438, Met437, Trp430, Tyr332, 


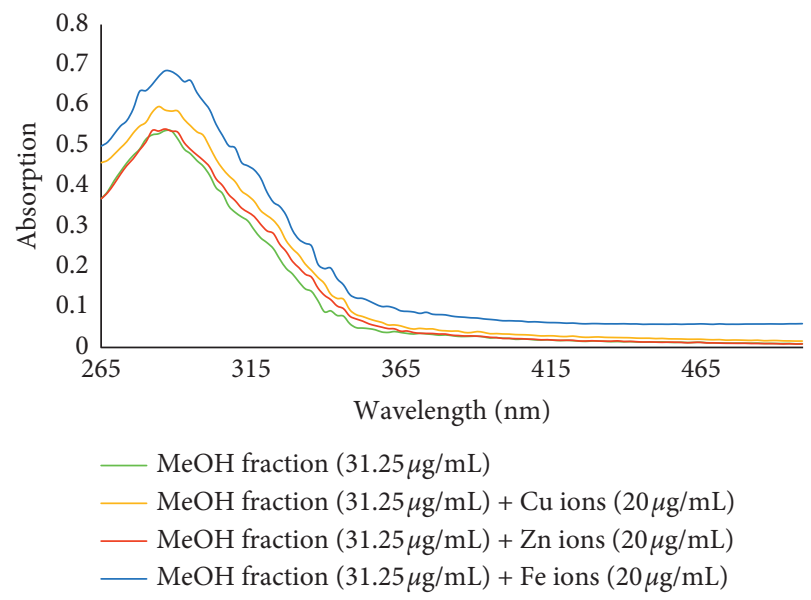

Figure 2: The absorbance changes of $\mathrm{MeOH}$ fraction alone and in the presence of $\mathrm{Zn}^{2+}, \mathrm{Fe}^{2+}$, and $\mathrm{Cu}^{2+}$ ions.

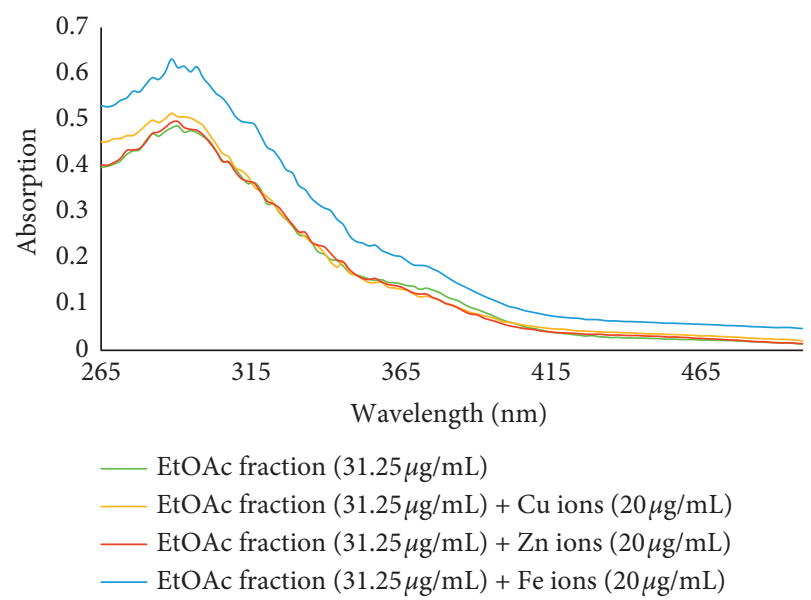

Figure 3: The absorbance changes of EtOAc fraction alone and in the presence of $\mathrm{Zn}^{2+}, \mathrm{Fe}^{2+}$, and $\mathrm{Cu}^{2+}$ ions.

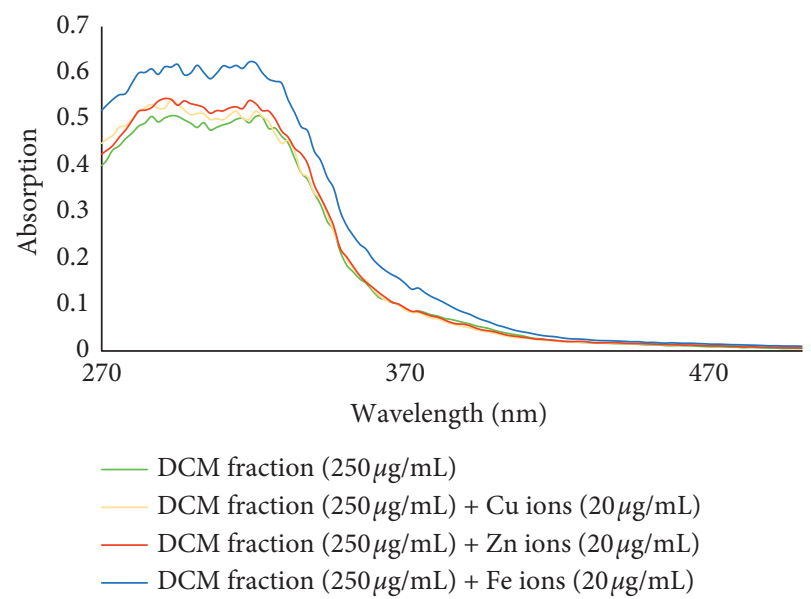

Figure 4: The absorbance changes of DCM fraction alone and in the presence of $\mathrm{Zn}^{2+}, \mathrm{Fe}^{2+}$, and $\mathrm{Cu}^{2+}$ ions.

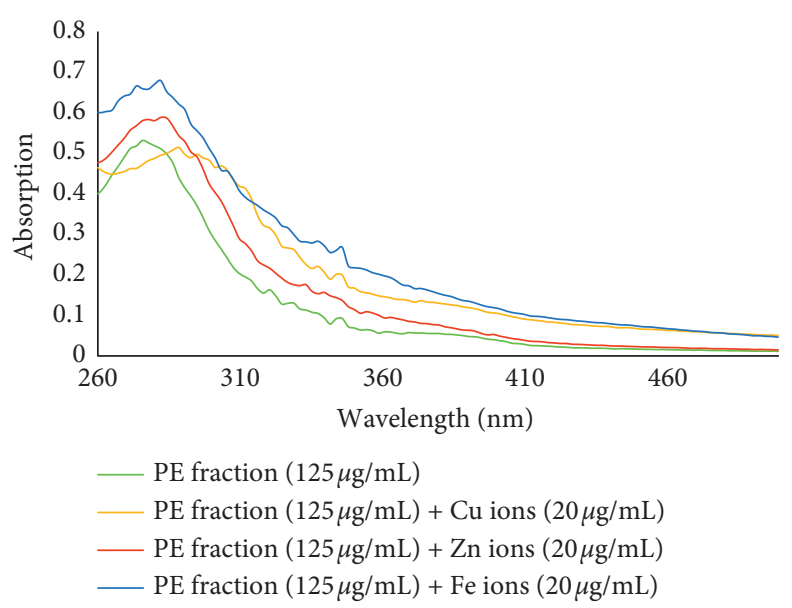

Figure 5: The absorbance changes of PE fraction alone and in the presence of $\mathrm{Zn}^{2+}, \mathrm{Fe}^{2+}$, and $\mathrm{Cu}^{2+}$ ions.

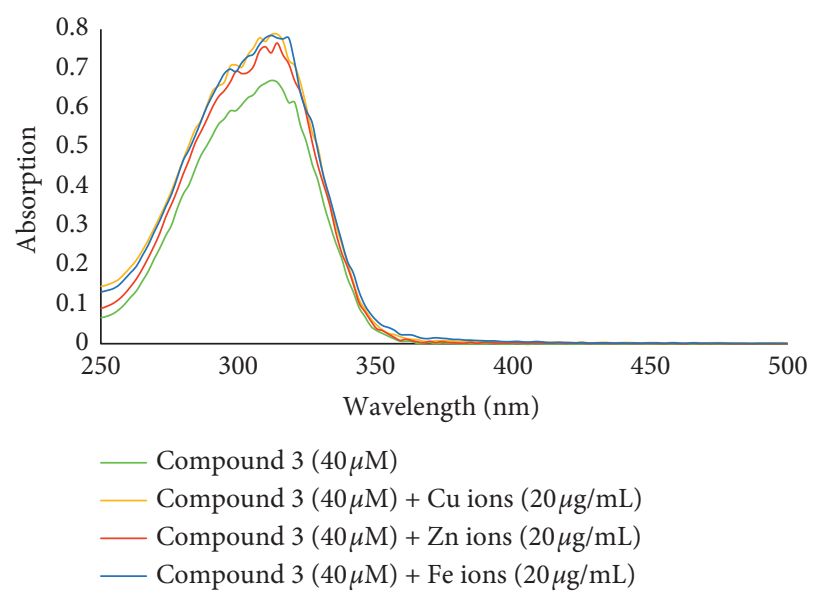

Figure 6: The absorbance changes of compound 3 alone and in the presence of $\mathrm{Zn}^{2+}, \mathrm{Fe}^{2+}$, and $\mathrm{Cu}^{2+}$ ions.

TABLE 3: Free radical scavenging activities of the fractions of L. inermis.

\begin{tabular}{lc}
\hline Fraction & $\mathrm{IC}_{50}(\mu \mathrm{g} / \mathrm{mL})$ \\
\hline PE & $29.40 \pm 1.61$ \\
DCM & $23.45 \pm 1.25$ \\
EtOAc & $3.08 \pm 0.10$ \\
MeOH & $3.64 \pm 0.03$ \\
BHA & $3.79 \pm 0.37$ \\
\hline
\end{tabular}

TABle 4: Molecular docking analysis of isolated compounds from L. inermis in the active site of AChE and BChE.

\begin{tabular}{lc}
\hline Compound & $\begin{array}{c}\text { Docking score }(\mathrm{kJ} / \mathrm{mol}) \\
\text { BChE (PDB: } 4 \mathrm{TPK})\end{array}$ \\
\hline $\mathbf{2}$ & -9.06 \\
$\mathbf{5}$ & -9.05 \\
Donepezil & -9.53 \\
\hline
\end{tabular}




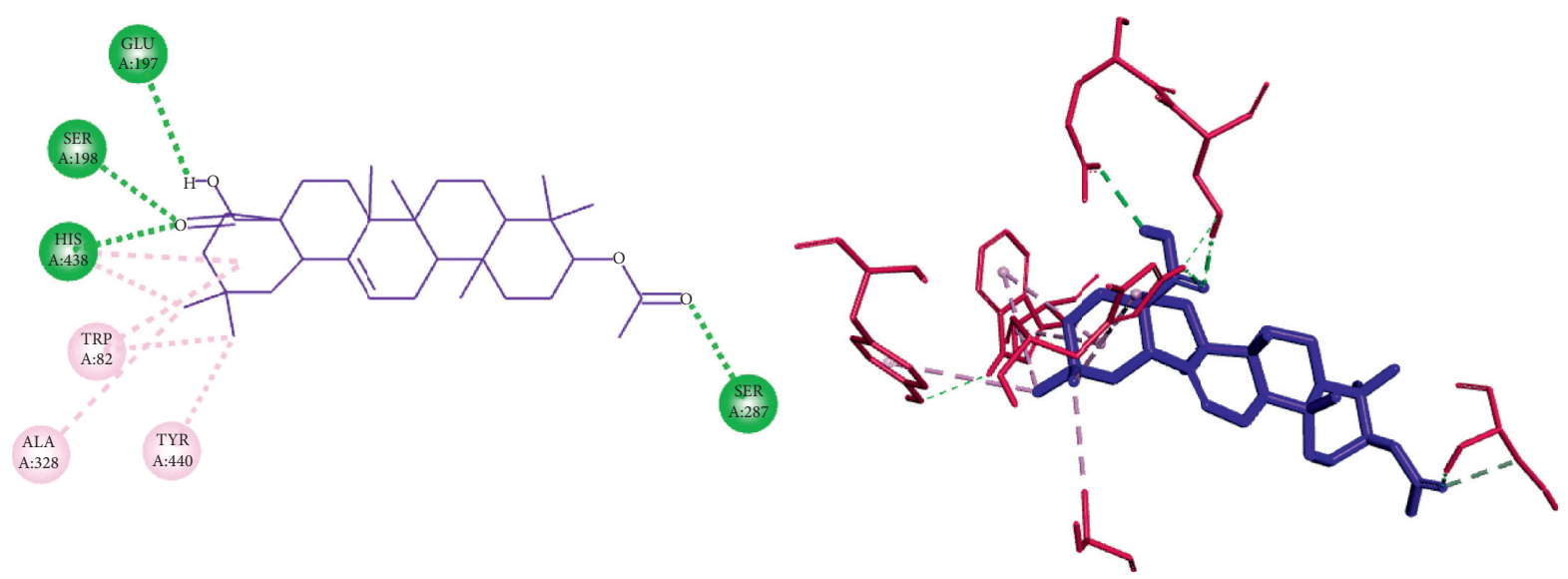

Interactions

Conventional hydrogen bond

Carbon hydrogan

Figure 7: Two- and three-dimensional representation of the docked pose of compound 2 into the binding pocket of the 4 TPK.

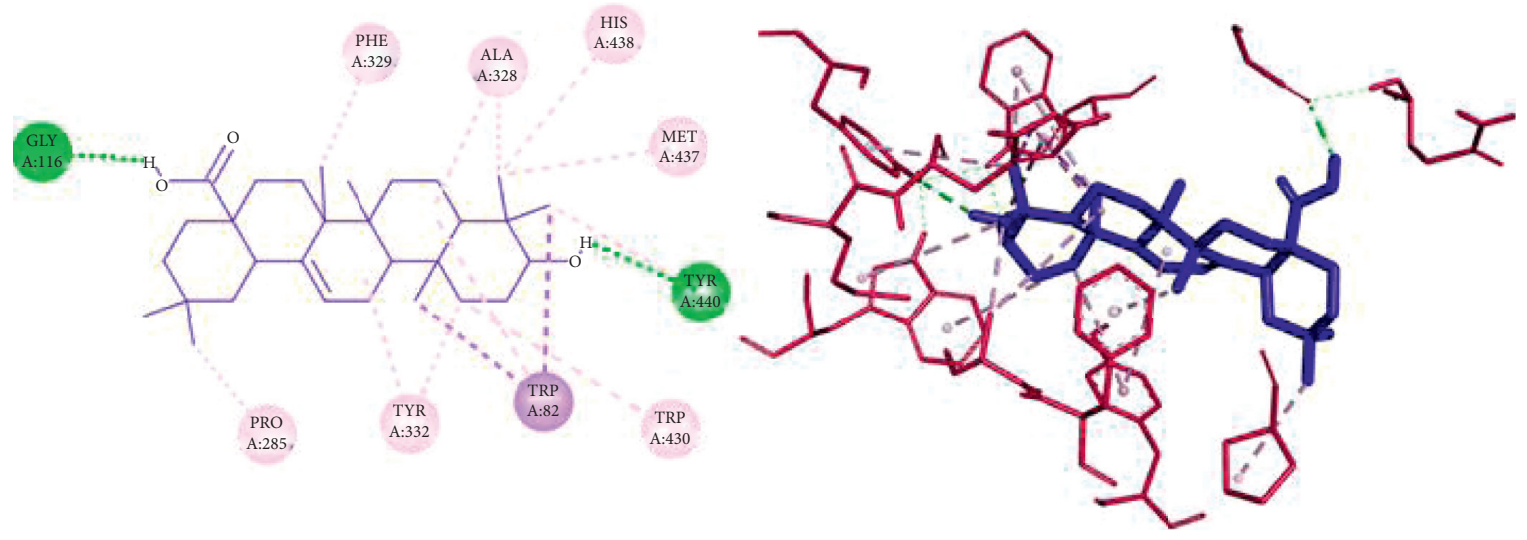

Interactions

Conventional hydrogen bond

Pi-sigma

Alkyl

Alkyl

Figure 8: Two- and three-dimensional representation of the docked pose of compound 5 into the binding pocket of the 4 TPK.

Tyr440, Trp82, and Pro285. Moreover, two pi-sigma interactions were formed between methyl groups and Trp82.

\section{Conclusion}

In this study, different biological activities of Lawsonia inermis $\mathrm{L}$. seeds related to $\mathrm{AD}$ as well as phytochemical analysis were investigated. In vitro anti-ChE activity of all fractions indicated potent and selective BChE inhibitory activity of the dichloromethane fraction which led to the isolation and identification of $\beta$-sitosterol (1), 3-O$\beta$-acetyloleanolic acid (2), 3-O-(Z)-coumaroyl oleanolic acid (3), betulinic acid (4), and oleanolic acid (5). Evaluation of compounds 1-5 toward $\mathrm{AChE}$ and $\mathrm{BChE}$ revealed that compounds $\mathbf{2}$ and $\mathbf{5}$ were the most potent and selective inhibitors of BChE with $\mathrm{IC}_{50}$ values of 77.13 and $72.20 \mu \mathrm{M}$, respectively. Furthermore, evaluation of the antioxidant and metal chelating ability of fractions and compounds confirmed the capability of $L$. inermis seeds to be considered in the treatment of $\mathrm{AD}$.

\section{Abbreviations}

L. inermis: Lawsonia inermis

AD: $\quad$ Alzheimer's disease

ACh: Acetylcholine

AChE: Acetylcholinesterase

AChEI: Acetylcholinesterase inhibitory

BChE: Butyrylcholinesterase

BChEI: Butyrylcholinesterase inhibitory

ChEs: Cholinesterases

DPPH: 2,2-diphenyl-1-picrylhydrazyl

$\mathrm{IC}_{50}$ : The half maximal inhibitory concentration

BHA: $\quad$ Butylated hydroxyanisole

NFTs: $\quad$ Neurofibrillary tangles

ROS: $\quad$ Reactive oxygen species

FDA: $\quad$ Food and Drug Administration

ITM: Iranian Traditional Medicine

${ }^{1}$ H NMR: Proton nuclear magnetic resonance

${ }^{13}$ C NMR: Carbon-13 nuclear magnetic resonance

HMQC: Heteronuclear multiple quantum correlation 
COSY: Correlation spectroscopy

HMBC: Heteronuclear multiple bond correlation

CC: Column chromatography

TLC: $\quad$ Thin-layer chromatography

UV: Ultraviolet radiation

ATCI: Acetylthiocholine iodide

DTNB: 5,5-Dithiobis-2-nitrobenzoic acid

MeOH: Methanol

EtOAc: Ethyl acetate

DCM: Dichloromethane

PE: $\quad$ Petroleum ether

ACE: Acetone.

\section{Data Availability}

The datasets generated during and/or analyzed during the current study are available from the corresponding author on reasonable request.

\section{Conflicts of Interest}

The authors declare that there are no conflicts of interest regarding the publication of this paper.

\section{Acknowledgments}

The authors acknowledge the support from Tehran University of Medical Sciences. This work was supported by Research Council of Tehran University of Medical Sciences under project no. 97-03-33-40260.

\section{References}

[1] J. M. Tublin, J. M. Adelstein, F. Del monte, C. K. Combs, and L. E. Wold, "Getting to the heart of alzheimer disease," Circulation Research, vol. 124, no. 1, pp. 142-149, 2019.

[2] C. Mount and C. Downton, "Alzheimer disease: progress or profit?” Nature Medicine, vol. 12, no. 7, pp. 780-784, 2006.

[3] R. E. Becker, N. H. Greig, E. Giacobini, L. S. Schneider, and L. Ferrucci, "A new roadmap for drug development for Alzheimer's disease," Nature Reviews Drug Discovery, vol. 13, no. 2, 156 pages, 2014.

[4] R. N. Kalaria, G. E. Maestre, R. Arizaga et al., "Alzheimer's disease and vascular dementia in developing countries: prevalence, management, and risk factors," The Lancet Neurology, vol. 7, no. 9, pp. 812-826, 2008.

[5] Y.-J. Cheng, C.-H. Lin, and H.-Y. Lane, "Involvement of cholinergic, adrenergic, and glutamatergic network modulation with cognitive dysfunction in alzheimer' disease," International Journal of Molecular Sciences, vol. 22, no. 5, p. 2283, 2021.

[6] D. T. Ohm, A. J. Fought, A. Martersteck et al., "Accumulation of neurofibrillary tangles and activated microglia is associated with lower neuron densities in the aphasic variant of Alzheimer's disease," Brain Pathology, vol. 31, no. 1, pp. 189-204, 2021.

[7] P. Picone, D. Nuzzo, D. Giacomazza, and M. Di carlo, " $\beta$-Amyloid peptide: the cell compartment multi-faceted interaction in alzheimer's disease," Neurotoxicity Research, vol. 37, no. 2, pp. 250-263, 2020.

[8] L. M. F. Gomes, J. C. Bataglioli, and T. Storr, "Metal complexes that bind to the amyloid- $\beta$ peptide of relevance to
Alzheimer's disease," Coordination Chemistry Reviews, vol. 412, Article ID 213255, 2020.

[9] M. F. Cano-Abad, M. Villarroya, A. G. Garćia, N. H. Gabilan, and M. G. López, "Calcium entry through L-type calcium channels causes mitochondrial disruption and chromaffin cell death," Journal of Biological Chemistry, vol. 276, no. 43, pp. 39695-39704, 2001.

[10] A. H. Bhat, K. B. Dar, S. Anees et al., "Oxidative stress, mitochondrial dysfunction and neurodegenerative diseases; a mechanistic insight," Biomedicine \& Pharmacotherapy, vol. 74, pp. 101-110, 2015.

[11] P. T. Francis, A. M. Palmer, M. Snape, and G. K. Wilcock, "The cholinergic hypothesis of Alzheimer's disease: a review of progress," Journal of Neurology, Neurosurgery \& Psychiatry, vol. 66, no. 2, pp. 137-147, 1999.

[12] A. Chatonnet and O. Lockridge, "Comparison of butyrylcholinesterase and acetylcholinesterase," Biochemical Journal, vol. 260, no. 3, pp. 625-634, 1989.

[13] J. Massoulié, L. Pezzementi, S. Bon, E. Krejci, and F.-M. Vallette, "Molecular and cellular biology of cholinesterases," Progress in Neurobiology, vol. 41, no. 1, pp. 31-91, 1993.

[14] P. Anand and B. Singh, "A review on cholinesterase inhibitors for Alzheimer's disease," Archives of Pharmacal Research, vol. 36, no. 4, pp. 375-399, 2013.

[15] V. S. Camara, A. J. Soares, B. Biscussi, A. P. Murray, and M. A. Ceschi, "Expedient microwave-assisted synthesis of bis (n)-lophine analogues as selective butyrylcholinesterase inhibitors: cytotoxicity evaluation and molecular modelling," Journal of the Brazilian Chemical Society, vol. 32, no. 6, pp. 1173-1185, 2021.

[16] V. P. Chen, Y. Gao, L. Geng, R. J. Parks, Y.-P. Pang, and S. Brimijoin, "Plasma butyrylcholinesterase regulates ghrelin to control aggression," Proceedings of the National Academy of Sciences, vol. 112, no. 7, pp. 2251-2256, 2015.

[17] A. Tasker, E. K. Perry, and C. G. Ballard, "Butyrylcholinesterase: impact on symptoms and progression of cognitive impairment," Expert Review of Neurotherapeutics, vol. 5, no. 1, pp. 101-106, 2005.

[18] M. Bortolami, D. Rocco, A. Messore et al., "Acetylcholinesterase inhibitors for the treatment of Alzheimer's disease-a patent review (2016-present)," Expert Opinion on Therapeutic Patents, vol. 31, no. 5, pp. 399-420, 2021.

[19] S. Abubakar, B.-K. Khor, K.-Y. Khaw, V. Murugaiyah, and K.-L. Chan, "Cholinesterase inhibitory potential of Dillenia suffruticosa chemical constituents and protective effect against $\mathrm{A} \beta$-induced toxicity in transgenic Caenorhabditis elegans model," Phytomedicine Plus, vol. 1, no. 1, Article ID 100022, 2021.

[20] M.-S. García-Ayllón, D. H. Small, J. Avila, and J. Saez-Valero, "Revisiting the role of acetylcholinesterase in Alzheimer's disease: cross-talk with P-tau and $\beta$-amyloid," Frontiers in Molecular Neuroscience, vol. 4, p. 22, 2011.

[21] J. L. Cummings, G. Tong, and C. Ballard, "Treatment combinations for Alzheimer's disease: current and future pharmacotherapy options," Journal of Alzheimer's Disease, vol. 67, no. 3, pp. 779-794, 2019.

[22] M. Balaei-Kahnamoei, M. Bozorgi, M. Khanavi et al., "Study of henna in Persian medicine and new studies," Journal of Islamic Iranian Traditional Medicine, vol. 10, no. 1, pp. 57-69, 2019.

[23] A. A. Elmanama, A. A. Alyazji, and N. Abu-Gheneima, "Antibacterial, antifungal and synergistic effect of Lawsonia inermis, Punica granatum and Hibiscus sabdariffa," Annals of Alquds Medicine, vol. 7, pp. 33-41, 2011. 
[24] B. Chengaiah, K. M. Rao, K. M. Kumar, M. Alagusundaram, and C. M. Chetty, "Medicinal importance of natural dyes-a review," International Journal of PharmTech Research, vol. 2, no. 1, pp. 144-154, 2010.

[25] B. Ajitha, Y. A. K. Reddy, P. S. Reddy, Y. Suneetha, H.-J. Jeon, and C. W. Ahn, "Instant biosynthesis of silver nanoparticles using Lawsonia inermis leaf extract: innate catalytic, antimicrobial and antioxidant activities," Journal of Molecular Liquids, vol. 219, pp. 474-481, 2016.

[26] R. D. Tripathi, H. S. Srivastava, and S. N. Dixit, "A fungitoxic principle from the leaves of Lawsonia inermis Lam," Experientia, vol. 34, no. 1, pp. 51-52, 1978.

[27] M. A. Khorasani, Makhzan Al Advieh, Bavardaran Press Research institute for Islamic and Complementary Medicine, Iran University of Medical Sciences, Tehran, Iran, 2001.

[28] S. Omidpanah, Y. Vahedi-Mazdabadi, A. Manayi et al., "Phytochemical investigation and anticholinesterase activity of ethyl acetate fraction of myristica fragrans houtt. seeds," Natural Product Research, pp. 1-7, 2020.

[29] M. Saeedi, Y. Vahedi-Mazdabadi, A. Rastegari, M. Soleimani, M. Eftekhari, and T. Akbarzadeh, "Evaluation of asarum europaeum L. Rhizome for the biological activities related to Alzheimer's disease," Research Journal of Pharmacognosy, vol. 7, no. 3, pp. 25-33, 2020.

[30] S. Rahmani-Nezhad, S. Dianat, Z. Fooladi et al., "Investigation of polysaccharide extracts from Iranian and French strains of Agaricus subrufescens against enzymes involved in Alzheimer's disease," Boletín Latinoamericano y del Caribe de Plantas Medicinales y Aromáticas, vol. 18, no. 6, pp. 544-554, 2019.

[31] Y. Vahedi-Mazdabadi, E. Karimpour-Razkenari, T. Akbarzadeh et al., "Anti-cholinesterase and neuroprotective activities of sweet and bitter apricot kernels (prunus armeniaca L.)," Iranian Journal of Pharmaceutical Research: IJPR, vol. 19, no. 4, p. 216, 2020.

[32] M. Bozorgi, Z. Najafi, S. Omidpanah et al., "Investigation of anti-Alzheimer's activity of aqueous extract of areca nuts (Areca catechu L.): in vitro and in vivo studies," Boletin Latinoamericano y del Caribe de Plantas Medicinales y Aromaticas, vol. 20, no. 4, pp. 406-415, 2021.

[33] G. L. Ellman, K. D. Courtney, V. Andres, and R. M. Featherstone, "A new and rapid colorimetric determination of acetylcholinesterase activity," Biochemical Pharmacology, vol. 7, no. 2, pp. 88-95, 1961.

[34] A. Rastegari, H. Nadri, M. Mahdavi et al., "Design, synthesis and anti-Alzheimer's activity of novel 1, 2, 3-triazole-chromenone carboxamide derivatives," Bioorganic Chemistry, vol. 83, pp. 391-401, 2019.

[35] I. E. Orhan, F. S. Senol, S. Shekfeh, K. Skalicka-Wozniak, and E. Banoglu, "Pteryxin-a promising butyrylcholinesteraseinhibiting coumarin derivative from Mutellina purpurea," Food and Chemical Toxicology, vol. 109, pp. 970-974, 2017.

[36] M. Balaei-Kahnamoei, M. Eftekhari, M. R. Shams-Ardekani et al., "Phytochemical constituents and biological activities of Salvia macrosiphon Boiss," BMC Chemistry, vol. 15, no. 1, pp. 1-7, 2021.

[37] Y. Jo, J. Suh, M. H. Shin, J. H. Jung, and K. S. Im, "Jacaranone and related compounds from the fresh fruits ofTernstroemia japonica and their antioxidative activity," Archives of Pharmacal Research, vol. 28, no. 8, pp. 885-888, 2005.

[38] C.-R. Liao, Y.-H. Kuo, Y.-L. Ho et al., "Studies on cytotoxic constituents from the leaves of Elaeagnus oldhamii maxim. in non-small cell lung cancer A549 cells," Molecules, vol. 19, no. 7, pp. 9515-9534, 2014.
[39] M. Sholichin, K. Yamasaki, R. Kasai, and O. Tanaka, “^C nuclear magnetic resonance of lupane-type triterpenes, lupeol, betulin and betulinic acid," Chemical and Pharmaceutical Bulletin, vol. 28, no. 3, pp. 1006-1008, 1980.

[40] S. R. Samarakoon, M. K. Ediriweera, L. Wijayabandara et al., "Isolation of cytotoxic triterpenes from the mangrove plant, Scyphiphora hydrophyllacea C.F. Gaertn (Rubiaceae)," Tropical Journal of Pharmaceutical Research, vol. 17, no. 3, pp. 475-481, 2018.

[41] G. Pentón-Rol and M. Cervantes-Llanos, "Report on the symposium "molecular mechanisms involved in neurodegeneration"” Behavioral Sciences, vol. 8, no. 1, p. 16, 2018.

[42] M. Saeedi, A. Rastegari, R. Hariri et al., "Design and synthesis of novel arylisoxazole-chromenone carboxamides: investigation of biological activities associated with Alzheimer's disease," Chemistry \& Biodiversity, vol. 17, no. 5, Article ID e1900746, 2020.

[43] L. Jing, G. Wu, D. Kang et al., "Contemporary medicinalchemistry strategies for the discovery of selective butyrylcholinesterase inhibitors," Drug Discovery Today, vol. 24, no. 2, pp. 629-635, 2019.

[44] I. Lee, B. Ahn, J. Choi, M. Hattori, B. Min, and K. Bae, "Selective cholinesterase inhibition by lanostane triterpenes from fruiting bodies of Ganoderma lucidum," Bioorganic \& Medicinal Chemistry Letters, vol. 21, no. 21, pp. 6603-6607, 2011.

[45] F. Ahmed, R. Ghalib, P. Sasikala, and K. Mueen Ahmed, "Cholinesterase inhibitors from botanicals," Pharmacognosy Reviews, vol. 7, no. 14, p. 121, 2013.

[46] B. Liu, L. Yang, Y.-K. Xu, S.-G. Liao, H.-R. Luo, and Z. Na, "Two new triterpenoids from Gelsemium elegans and Aglaia odorata," Natural Product Communications, vol. 8, no. 10, Article ID 1934578X1300801008, 2013.

[47] H. Amat-ur-Rasool, F. Symes, D. Tooth et al., "Potential nutraceutical properties of leaves from several commonly cultivated plants," Biomolecules, vol. 10, no. 11, p. 1556, 2020.

[48] V. Rajesh, T. Riju, S. Venkatesh, and G. Babu, "Memory enhancing activity of Lawsonia inermis Linn. leaves against scopolamine induced memory impairment in Swiss albino mice," Oriental Pharmacy and Experimental Medicine, vol. 17, no. 2, pp. 127-142, 2017.

[49] N. T. Mir, U. Saleem, F. Anwar et al., "Lawsonia Inermis markedly improves cognitive functions in animal models and modulate oxidative stress markers in the brain," Medicina, vol. 55, no. 5, p. 192, 2019. 